\title{
Analysing the System of Settlements in Slovenia: Traditional and Alternative Approach
}

\author{
Kušar Simon ${ }^{A}$ \\ Received: July 2012 | Revised: February 2013 | Accepted: February 2013
}

\begin{abstract}
The structure of the system of settlements in Slovenia is presented through traditional approach of quantitative analysis of basic characteristics of the settlement network in Slovenia, the system of central places, the system of urban settlements, through description of the planned (future) system of settlements in Slovenia as seen in the Spatial Development Strategy of Slovenia and in an alternative way through categorization of settlements in Slovenia by using several indicators. The system of settlements in Slovenia is characterized by dispersion of its 6,000 settlements and low level of urbanization. There are many rural settlements with emphasized dwelling function, small towns and only two larger towns. Spatial development trends indicate that the dispersion will stay an important spatial element, but causing environmental pressures. The dispersion will have many positive effects on regional development of Slovenia's regions as well.
\end{abstract}

Key words: System of settlements, economic geography, spatial planning, regional planning, Slovenia

\section{Introduction}

The Republic of Slovenia is characterized by a large number of settlements. Although the national territory extends on the $20,273 \mathrm{~km}^{2}$, there are more than 6,000 settlements registered. The number of settlements is approximately the same as in the Republic of Serbia (6,155 settlements - Tosić, 2009), but the Republic of Serbia is 4.4 times larger than Republic of Slovenia. Therefore, settlements are important landscape element of Slovenia that needs to be taken into consideration in geographical analysis of Slovenia and in shaping its regional and spatial development strategies.

Settlements in Slovenia were of particular interest to geographers and other social scientists from the beginning of the modern geographical science in Slovenia. The analysis of settlements was included in first general monograph presenting the Slovenian territory by Melik (1935). Settlements and their system are presented also in monographs published after the independence in 1991 describing geographical characteristics of Slovenia: Lexicon of place names of Slovenia,
Slovenia - regions and people, Geographical atlas of Slovenia, National atlas of Slovenia (Orožen Adamič, 2004). In 2004, Association of the geographical societies of Slovenia prepared the scientific monograph Slovenia - a geographical overview, where Kladnik (2004) and Ravbar (2004) published a short analysis of settlements and the system of settlements and urbanization in Slovenia.

The system of settlements in Slovenia was studied carefully especially at the end of the 1960s while preparing the regional spatial plan of Slovenia. At that time geographers developed the concept of the polycentric urban system of Slovenia (Kokole, 1975) that is, although revised, still in operation. Kokole and Vrišer started also research on the central place system that was examined recently by Cigale and Benkovič Krašovec (Černe, et al., 2007). Vrišer (1980) studied the system of settlements in Slovenia in the system of settlements in Yugoslav federation. Urban and traffic system were analysed by Černe and Pelc (1992), and later by Černe and Kušar (2008). New categorization of settlements was prepared recently by

\footnotetext{
A Department of Geography, Faculty of Arts, University of Ljubljana, Aškerčeva 2, SI - 1000 Ljubljana, Slovenia; e-mail: simon.kusar@ff.uni-lj.si
} 
Černe and his colleagues (Černe, et al., 2007). The morphology of settlements was of geographers' research interest as well (Drozg, 2002). Rebernik (2004) was active in analysing socio-geographic structure of settlements, while Bole (2008) worked on economic transformation of urban settlements. Just recently, Zupančič (2007) opened a specific topic on spatial problems of the Roma settlements in Slovenia. As seen, the bibliography on settlements and the system of settlements in Slovenia is extensive; therefore, it is not possible to mention all relevant topics, authors and their work.

The aim of this article is to present basic characteristics and changes of the system of settlements in Slovenia at the beginning of the second decade of the 21st Century with special emphasis on the hierarchy and importance of settlements. To achieve the aim of the article different traditional approaches are used (the settlement network analysis, urban settlements, central settlements, planned polycentric urban system of settlements), but special emphasis is given to alternative approach for determination of the system of settlements in Slovenia trying to include several indicators. The latter approach was developed by Černe and the author of this article (Černe, et al., 2007).

Methods used in the survey are based on calculation of relative numbers and elaboration of the basic statistical analysis. The source of data is the database of the national statistical office, especially the register-based census data from 2011, analysis of geographical literature and spatial planning strategies. Results on the categorization of settlements in Slovenia as an alternative approach are presented and evaluated as well.

The first part of the article presents traditional approaches in analyzing the system of settlements: basic characteristics of the settlement network in Slovenia using the newest population statistics, analysis of central settlements and urban settlements together with the presentation of the planned network of settlements as defined in the national spatial development strategy. The second part of the article brings results of the categorization of settlements in Slovenia as an alternative approach in analyzing the system of settlements. The article concludes with a short summary of basic characteristics of the system of settlements in Slovenia, specific issues regarding the current and future development of the system of settlements in Slovenia and the possibilities for future research on the system of settlements in Slovenia.

\section{Analysing the system of settlements in Slovenia: traditional approaches}

\section{Basic characteristics of the settlement network}

According to data from the Register of Spatial Units, which is kept by the Surveying and Mapping Authority of the Republic of Slovenia there were 6,032 settlements in Slovenia on the 1st of April 2012 (Territorial units..., 2012). If there were $2.055,496$ inhabitants living in Slovenia at that time (first quarter of 2012; SIStat, 2012), then there were 341 inhabitants living on average in each settlement.

Table 1. Settlements with more than 10,000 inhabitants in Slovenia in 2011

\begin{tabular}{|l|r|r|r|}
\hline Settlement & $\begin{array}{c}\text { Number of } \\
\text { inhabitants (2002) }\end{array}$ & $\begin{array}{c}\text { \% of inhabitants in } \\
\text { Slovenia }\end{array}$ & $\begin{array}{c}\text { Cumulative \% of } \\
\text { inhabitants in Slovenia }\end{array}$ \\
\hline Ljubljana & 272,220 & 13.3 & 13.3 \\
\hline Maribor & 95,171 & 4.6 & 17.9 \\
\hline Celje & 37,520 & 1.8 & 19.7 \\
\hline Kranj & 36,874 & 1.8 & 21.5 \\
\hline Velenje & 25,456 & 1.2 & 22.7 \\
\hline Koper & 24,996 & 1.2 & 23.9 \\
\hline Novo mesto & 23,341 & 1.1 & 25.0 \\
\hline Ptuj & 18,164 & 0.9 & 25.9 \\
\hline Trbovlje & 15,163 & 0.7 & 26.6 \\
\hline Kamnik & 13,644 & 0.7 & 27.3 \\
\hline Jesenice & 13,440 & 0.7 & 28.0 \\
\hline Nova Gorica & 13,178 & 0.6 & 28.6 \\
\hline Domžale & 12,406 & 0.6 & 29.2 \\
\hline Škofja Loka & 11,969 & 0.6 & 29.8 \\
\hline Murska Sobota & 11,614 & 0.6 & 30.4 \\
\hline Izola & 11,223 & 0.5 & 30.9 \\
\hline
\end{tabular}

Source: SORS - 2011 Register-based Census 
Table 2. Groups of settlements in Slovenia according to the number of population in 2002

\begin{tabular}{|l|r|r|r|}
\hline Group & Number of settlements & \% of settlements & \% of inhabitants \\
\hline$>50,000$ & 2 & 0.0 & 17.9 \\
\hline $10,000-50,000$ & 14 & 0.2 & 13.1 \\
\hline $5,000-10,000$ & 23 & 0.4 & 7.5 \\
\hline $1,500-5,000$ & 104 & 1.8 & 12.8 \\
\hline $500-1,500$ & 416 & 6.9 & 15.9 \\
\hline $50-500$ & 3797 & 62.9 & 30.7 \\
\hline$<50$ & 1676 & 27.8 & 2.1 \\
\hline
\end{tabular}

Source: SORS - 2011 Register-based Census

Ljubljana, the capital of Slovenia, had 272,220 inhabitants (13.3\% of population in Slovenia in 2011). Ljubljana is the only settlement in Slovenia with more than 100,000 inhabitants, while Maribor, the second largest town in Slovenia, had 95,171 inhabitants in 2011. Ljubljana is 2.86 times larger than Maribor according to the number of inhabitants. Celje, the third largest settlement in Slovenia, had less than 40,000 inhabitants at the 2011 register-based census. Maribor is therefore almost two and a half time (2.54) larger than Celje, while Ljubljana is even 7.26 times larger than Celje. Only 16 settlements in Slovenia had more than
10,000 inhabitants in 2011 in which there lived almost one-third of the national population. One of the basic characteristics of the settlement network in Slovenia is therefore a small number of larger settlements.

With exception of Ljubljana and Maribor other towns in Slovenia are small. But on the other hand there are many small rural settlements: typical Slovene settlement has less than 500 inhabitants.

Rank-size relationship of settlements in Slovenia shows primacy of Ljubljana, the largest settlement in the system of settlements in Slovenia. But on the other end of the line there can be seen the influence of nu-

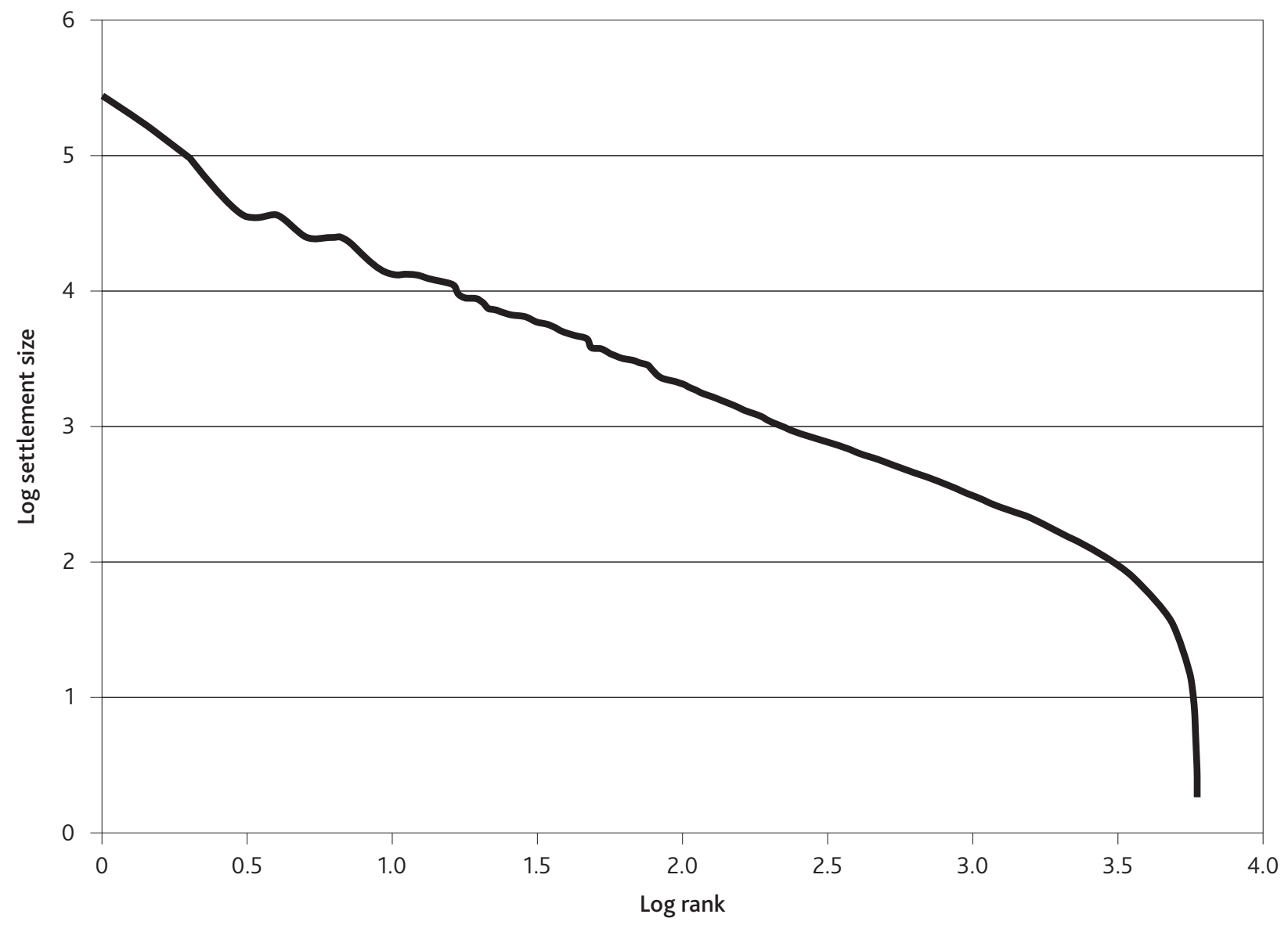

Figure 1. Rank-size relationship of settlements in Slovenia Source: SORS - 2011 Register-based Census 


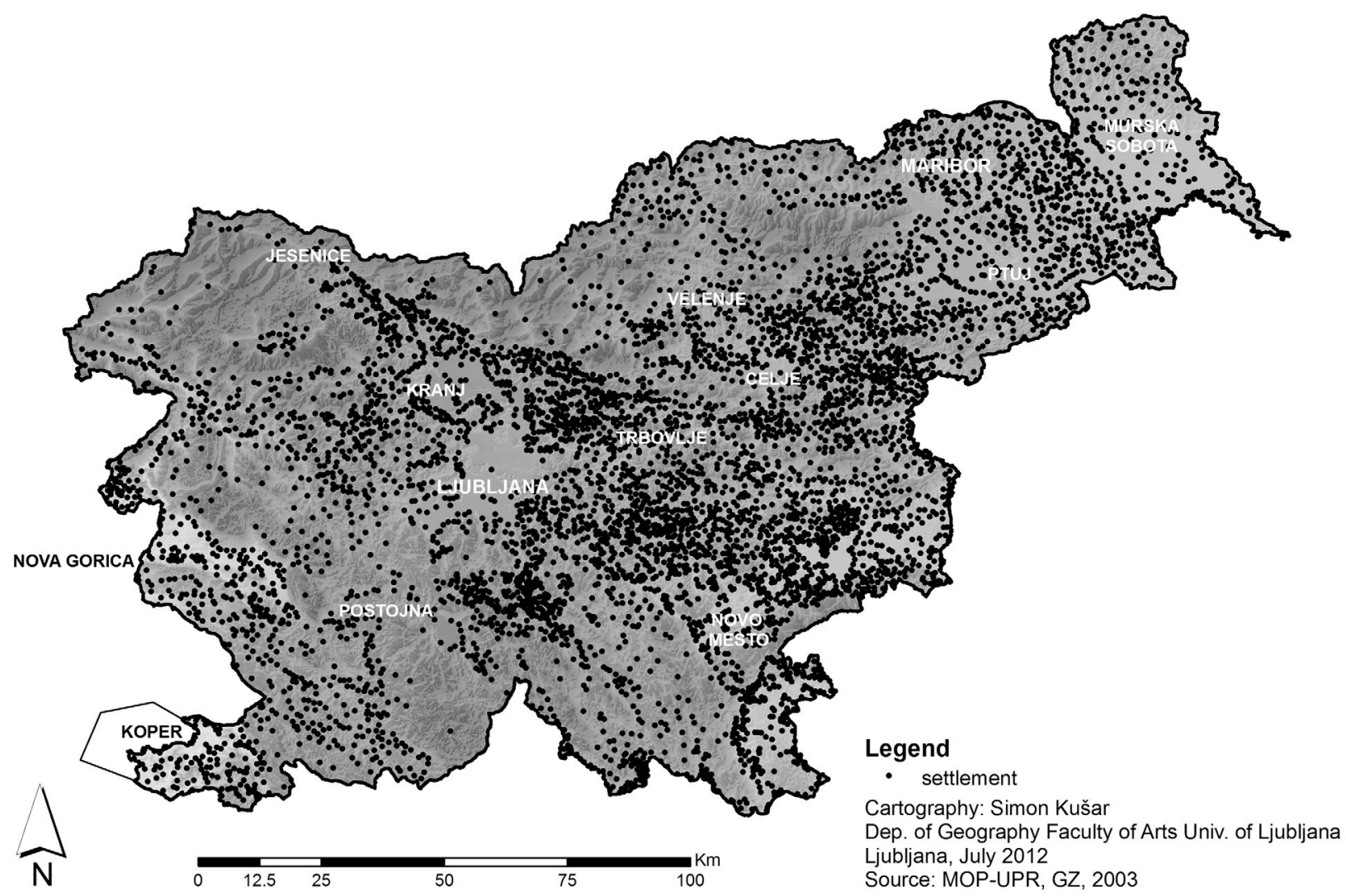

Figure 2. The network of settlements in Slovenia

merous small (rural) settlements. Distribution of settlements in Slovenia therefore shows unexpressive oligarchic pattern.

The second characteristic of settlement network in Slovenia is its dispersion. There are about 30 settlements for every $100 \mathrm{~km} 2$ on average therefore distances separating them are relatively small. The mean distance between settlements and their nearest neighbour (if we consider their random distribution) is slightly above one kilometre $(1.203 \mathrm{~km})$. The nearest neighbour index calculated from mean-distance between nearest settlements and mean-distance between randomly distributed settlements and their nearest neighbours (see Hammond, McCullagh, 1974) is surprisingly o.8187 ( $\mathrm{p}=$ $0,00)$ showing their (medium) clustering. Value of the nearest neighbour index must be interpreted through physical-geographical characteristics of Slovenia, because mountainous areas are less populated. Settlements in Slovenia are very dispersed especially in the pre-Alpine and the sub-Pannonian parts of Slovenia (central and eastern part of Slovenia), but it needs to be pointed out, that this is a unique characteristic of the cultural landscape of those areas.

Namely, the majority of Slovene settlements developed in the period when agriculture was the basic activity, which is also reflected in their location, density and size. There are still many isolated farmsteads, tiny hamlets, smaller or larger dispersed or compact settle- ments (Kladnik, 2004). Natural conditions were important for development of the network of settlements as well. Diverse relief of Slovenia was not suitable for centralization and growth of a single centre. Main administrative and economic centres on the territory of Slovenia which developed in the second half of the 19th century after construction of first railroads and especially after the Second World War with intensive industrialization became the backbone of the polycentric development that was later enhanced by official policy of polycentric development that highlighted the importance of regional centres and later of municipal centres.

Processes of deagrarization, industrialization, centralization and polycentric development policies from the 1960s on influenced on the development of some settlements, while others stagnated. The result is uneven distribution of population in Slovenia: sixth of the country has an above-average population density where four fifths of the population lives. Those areas are mostly in altitude belts below 400 meters, mainly around Slovenia's largest settlements, which are located on plains and along the shoreline of the Bay of Trieste. Almost tenth of Slovenia is unpopulated (Kladnik, 2004).

Areas around larger settlements (Ljubljana, Maribor, Celje, Koper, Kranj,...) experienced rapid development. Suburbanization occupies around one third of Slovenia's surface area. Suburbanized settlements include 
the extremely transformed villages found throughout the country. There are 280 settlements in the immediate suburban vicinity of larger settlements which are followed by another 660 very urbanized suburban settlements. In these two groups of settlements live more than 400,000 inhabitants. The next circle comprises 965 urbanized and semi-urbanized rural settlements with altogether 300,000 inhabitants. Other settlements are characterised as rural (Kladnik, 2004).

But even small rural settlements are modernised. Polycentric development of Slovenia and improvement in the quality of the road network enabled people living in the countryside in (transformed) rural settlements and commuting daily on their place of work. Therefore, small settlements in Slovenia are usually not typical rural settlements with agriculture as the most important economic activity of their residents: they have important dwelling functions, while rural centres also some services and manufacturing. Exceptions are found in less developed peripheral mountainous and border areas of Slovenia where centres of economic development are often too far or are less powerful. Depopulated less developed areas cover almost one-half of the national territory.

\section{Urban settlements in Slovenia}

When discussing the role of urban settlement in Slovenia, it needs to be pointed out, that level of urbanization reaches only $50 \%$. The official level of urbanisation was around $50 \%$ in 2011 therefore half of Slovenians live on the countryside. But a vast majority of them work in manufacturing and service sector, since agriculture employs only $4 \%$ of active population in Slovenia. The countryside is urbanized, especially around larger settlements. Suburbanization and periurbanization are important geographical processes, because residents are leaving towns to live in the countryside with lower prices of dwellings and better quality of life. But this is possible only on areas with good infrastructure that links settlements with important economic centres.

Which Slovene settlement is a town? According to the local self-government act from 1994 a town is a larger urban settlement that in terms of size, economic structure, population density and historical development differs from other settlements. A town needs to have more than 3,000 inhabitants. A settlement obtains town status by decision of the National Assembly of Republic of Slovenia (Regulations..., 1999).

National Assembly of Republic of Slovenia confirmed the "town" status for 51 settlements in Slovenia. Some municipal councils declared another 7 towns. Therefore there are 58 settlements in Slovenia with the status of "towns" (Kušar, Pichler-Milanović, 2010). There are also some other (urban) settlements that don't have a "town" status despite fulfilment of criteria defined by the Local Self-government Act (Urban settlements..., 2004).

There are different concepts how to define urban settlements, namely, each social science (geography as well) uses its own criteria to define them. In order to prepare the unified list of urban settlements experts from the national statistical office decided to use the method that is entirely based on statistical data. The most recent list of urban settlements and settlements in urban areas was prepared in 2003 and is used exclusively for statistical surveys and analysis. Indicators that were used for their definition are joined into four groups of criteria: number of population, morphology (population density, built-up areas), functions (number of jobs, daily migrants, transport connections, services) and structural indicators (e.g. number of farms) (Urban settlements..., 2004).

According to all four above mentioned criteria the list of urban settlements and settlements in urban areas includes 156 settlements in 104 urban areas, which can each be represented by one urban settlement or an urban settlement with suburban settlements (Urban settlements..., 2004). All towns are also urban settlements except from Višnja Gora and Kostanjevica na Krki. Both settlements retained the status due to historic reasons.

Taking into account the 2011 register-based census data, when total population of Slovenia was counted to $2.050,189$, a little more than one million of population was living in urban settlements. That gives the urbanisation rate of $49.9 \%$.

Local self-government act defines also municipalities (NUTS 5) with special status: "urban municipalities". Urban municipality is a densely populated settlement(s) of a unique territory inter-linked with daily migrations of population. The town is granted a status of urban municipality when having at least 20,000 inhabitants and 15,000 jobs of which more than half are in service sector and represent geographic, economic and cultural centre of the functional urban area. The status of urban municipality needs to be confirmed by the National Assembly of Republic of Slovenia after the local (municipal) referendum. Among 212 municipalities currently being in operation in Slovenia, only 11 municipalities have the status of urban municipalities: Celje, Koper, Kranj, Ljubljana, Maribor, Murska Sobota, Nova Gorica, Novo mesto, Ptuj, Slovenj Gradec, and Velenje. Urban municipalities need to have services which are typical for central places of higher hierarchical levels (Regulations..., 1999).

\section{The system of central settlements in Slovenia}

Central places are basic centres in the spatial organization of human society. They are usually determined 


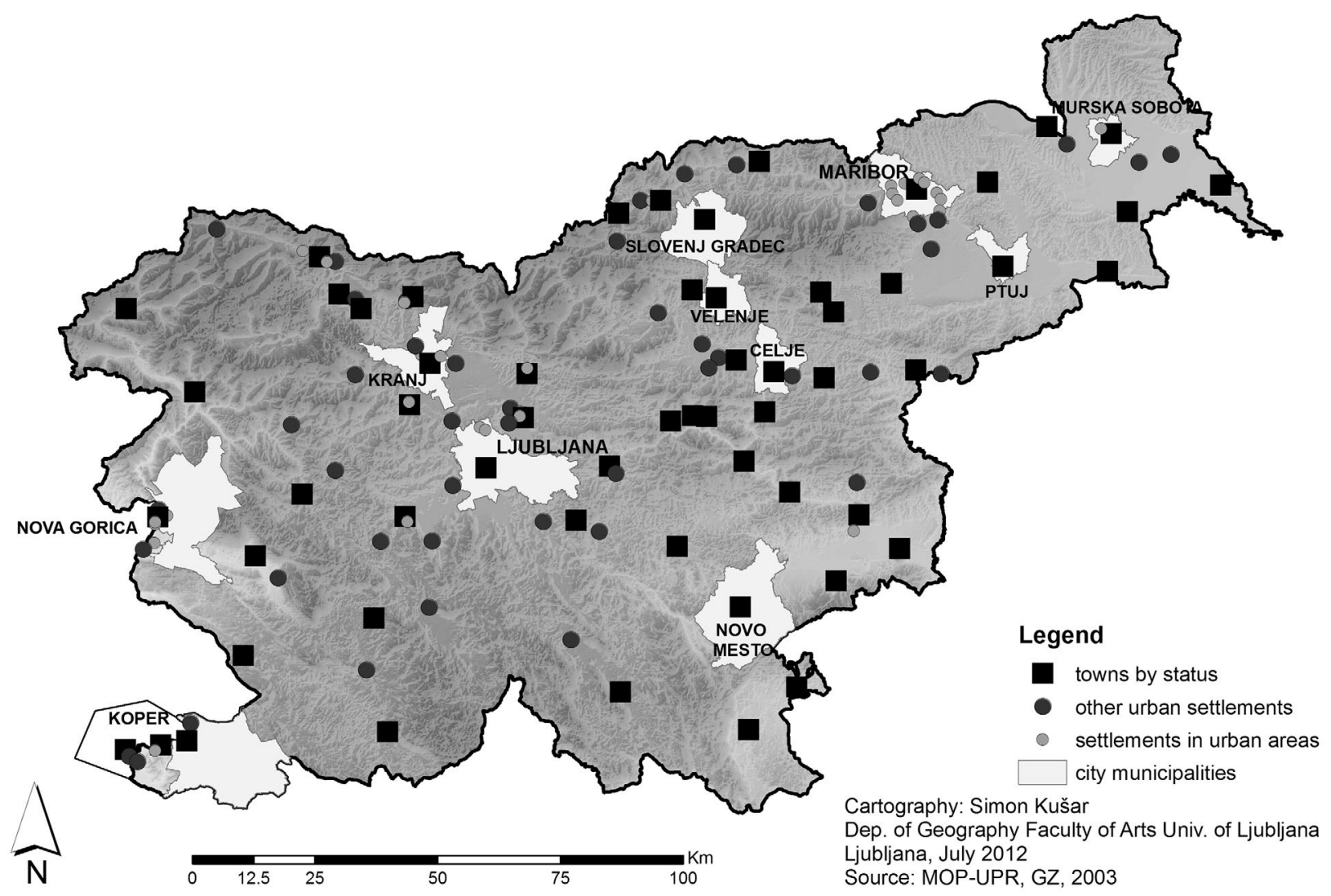

Figure 3. City municipalities, towns, urban settlements and settlements in urban areas in Slovenia Source: Adapted from Urban settlements..., 2004

on the basis of the importance of central place activities (selected service activities) and on the basis of determination of functional significance of central places within the network of all settlements through their gravitational influences. Central places are arranged in the hierarchy, so that central settlements of a higher hierarchical level have various more demanding functions along with basic ones (Černe, et al., 2007).

The network of central settlements in Slovenia has been influenced primarily by uneven distribution of population, the surface relief, historical development and the political and administrative division of the territory (Kladnik, 2004).

First studies of central places in Slovenia date in the late 1960s, when I. Vrišer and V. Kokole defined central places in Slovenia, their hierarchy and gravitational influence. V. Kokole prepared a new thorough research on central places in Slovenia in 1971 as well. The next important milestone in analysing central places in Slovenia was in 1987, when I. Vrišer prepared a new categorization of central places in Slovenia. $\mathrm{He}$ used almost the same indicators as in his previous research. He defined 600 central places in seven hierarchical levels. I. Vrišer prepared a new analysis of central places also in 1994 using the same methodology as in 1987. He defined 612 central places (Černe, at al., 2007).
The latest research on central places in Slovenia was conducted by D. Cigale (published in 2002) and M. Benkovič Krašovec (published in 2006). These two researches are also the basis of the following short presentation of central places in Slovenia.

D. Cigale prepared the study of central-place relationship in Slovenia in 1999. He discussed only the role of central places of higher ranks. His method was very similar to previous ones: schools were asked to define where local population obtains different goods and services which were included in the questionnaire. On the basis of the questionnaire and statistical data about provision of central places with different services he distinguished two macro-regional centres (Ljubljana, Maribor), 17 mezzo-regional centres and 79 micro-regional centres. Beside this hierarchical structure Cigale (2002) pointed out, that there were also numerous smaller, less important centres on lower hierarchical levels (Cigale, 2002).

Lower hierarchical levels of central places in Slovenia were thoroughly studied by M. Benkovič Krašovec (2006). According to presence of selected service activities in settlements she defined 358 central places of the first degree (sub-local centres) and 132 local centres i. e. settlements of the second degree (Černe, at al., 2007).

The system of more than 6,00o settlements in Slovenia comprises less than $10 \%$ (588 or $9.7 \%$ ) of set- 


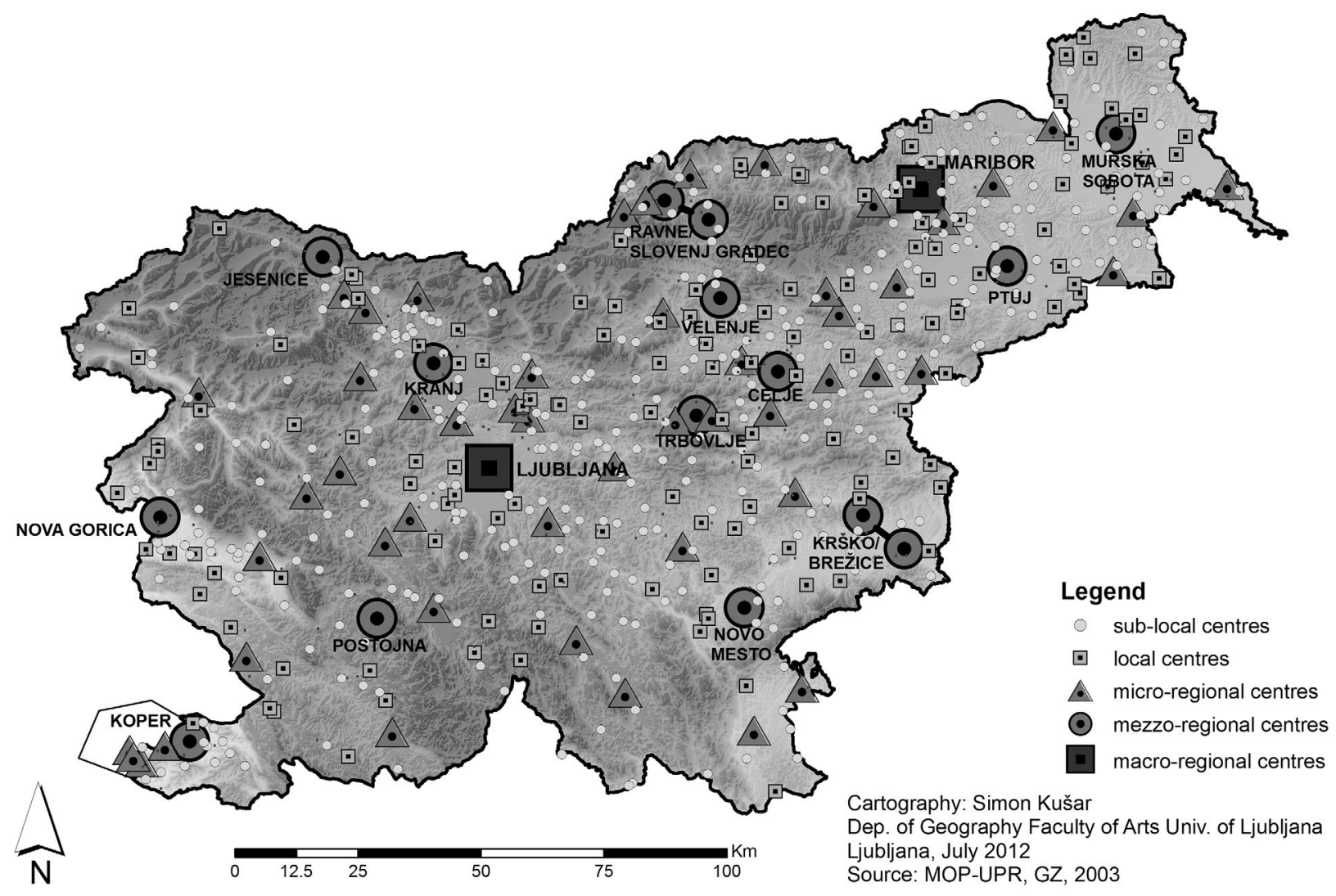

Figure 4. Central places in Slovenia in the middle of the first decade of the 21st century Source: Adapted from Kušar, Pichler-Milanović, 2010

tlements that have some role from the aspect of distribution of central place activities (Kušar, PichlerMilanović, 2010). But these settlements are very important for shaping economic, social and spatial structure of the territory of Slovenia.

\section{Planned (future) system of settlements in Slovenia}

Basic strategic document on the national level that plans development of the system of settlements in Slovenia is Spatial Development Strategy of Slovenia (2004). It provides the framework for spatial development across the entire national territory and sets guidelines for development within the European space. It provides also the concept of spatial planning and management, land use and spatial protection.

One of the goals of Spatial Development Strategy of Slovenia (2004) is also polycentric development of the network of towns and other settlements therefore the strategy continues the paradigm of polycentric development that is primary guideline for development of settlements in Slovenia from 196os on. Special attention is given to development of urban centres with national and regional significance as centres of regional territories. Strategy encourages also functional and infrastructural integration of cities, towns and other settlements.

The basic framework of the urban system is polycentric network of centres of national and region-

Table 3. The concept of the system of settlements in Slovenia as defined in Spatial Development Strategy of Slovenia

\begin{tabular}{|c|c|c|c|}
\hline $\begin{array}{l}\text { National urban centres of } \\
\text { international significance (3) }\end{array}$ & $\begin{array}{l}\text { Urban centres of national } \\
\text { significance (12) }\end{array}$ & $\begin{array}{l}\text { Urban centres of regional } \\
\text { significance (15) }\end{array}$ & $\begin{array}{l}\text { Urban centres of inter- } \\
\text { municipal significance (20) }\end{array}$ \\
\hline $\begin{array}{l}\text { Ljubljana, Maribor, Koper- } \\
\text { Izola-Piran }\end{array}$ & $\begin{array}{l}\text { Celje, Kranj, Murska Sobota, } \\
\text { Nova Gorica, Novo mesto, } \\
\text { Postojna, Ptuj, Velenje, } \\
\text { Brežice-Krško-Sevnica, } \\
\text { Jesenice-Radovljica, Slovenj } \\
\text { Gradec-Ravne na Koroškem- } \\
\text { Dravograd, Trbovlje-Hrastnik- } \\
\text { Zagornje ob Savi }\end{array}$ & $\begin{array}{l}\text { Ajdovščina, Črnomelj, } \\
\text { Domžale-Kamnik, Gornja } \\
\text { Radgona, Idrija, Ilirska } \\
\text { Bistrica, Kočevje, Lendava, } \\
\text { Ljutomer, Ormož, Sežana, } \\
\text { Škofja Loka, Šmarje pri Jelšah- } \\
\text { Rogaška Slatina, Tolmin, Tržič }\end{array}$ & $\begin{array}{l}\text { Bovec, Cerknica, Cerkno, } \\
\text { Gornji Petrovci, Grosuplje, } \\
\text { Laško, Lenart, Litija, Logatec, } \\
\text { Metlika, Mozirje, Radlje } \\
\text { ob Dravi, Ribnica, Ruše, } \\
\text { Slovenska Bistrica, Slovenske } \\
\text { Konjice, Šentjur, Trebnje, } \\
\text { Vrhnika, Žalec }\end{array}$ \\
\hline
\end{tabular}




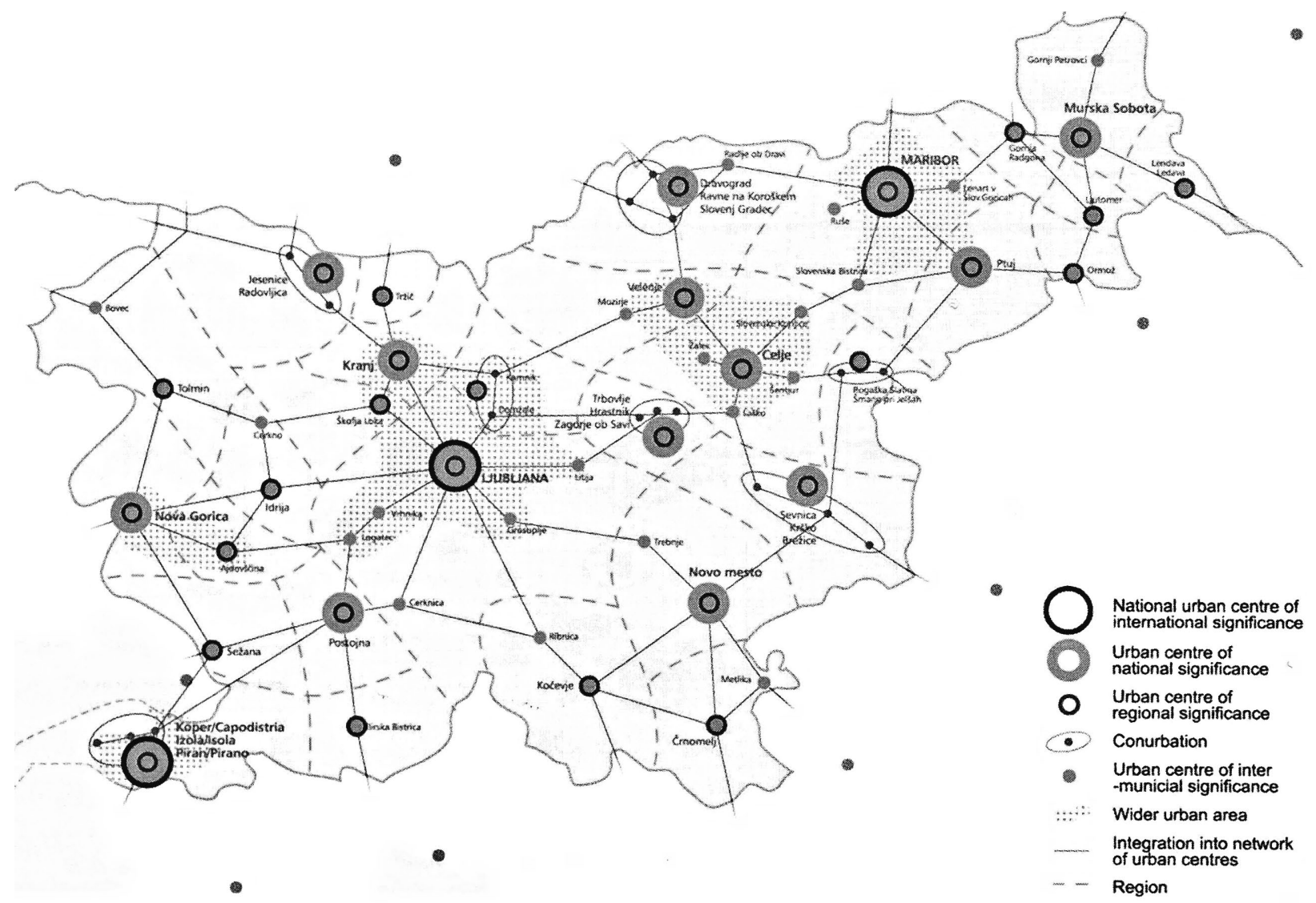

Figure 5. Polycentric Urban System in Slovenia

Source: Spatial Development Strategy of Slovenia, 2004

al significance. At the local level, the centres of intermunicipal significance, important local centres and other local centres should be developed with efficient and balanced accessibility, appropriate distribution of functions, and transport interconnections (Spatial..., 2004).

Urban settlements with at least 10,000 inhabitants and potentials for development of services, supply and other activities to be provided to the population in their areas of influence should be, according to Spatial Development Strategy of Slovenia (2004), developed as centres of national significance. There are 15 centres of national significance planned of which Ljubljana, Maribor and conurbation Koper-Izola-Piran are due to their role, size and position national urban centres of international significance. Beside coastal conurbation there are also some other conurbations of functionally and spatially linked urban settlements, that can develop as a centre of national or regional significance as well.

Regional centres and inter-municipal centres are the second level of the system of urban settlements in Slovenia. Regional centres are urban settlements with at least 5,00o inhabitants, whose gravitation areas are remote, hilly, mountainous, or border areas, or are far away from main transport corridors. Inter-municipal centres should be given priority in development as well, because they are important for provision of services for peripheral or hilly areas or are spatially remote from other important centres (Spatial..., 2004).

\section{Alternative approach: Categorization of settlements in Slovenia}

\section{Methods and data}

The starting point for alternative analysis of the system of settlements in Slovenia is the notion that functions of settlements according to location of central activities are just one of the basic elements that are presenting a complex significance of settlements and their cohesion. Functional significance of a settlement is dependent also of other factors, for example its size, geographical position, economic power and transport location which may, in great deal, determine the significance of individual settlement in the system of settlements. Therefore we used not just the degree of provision of a settlement with different central place activities for the categorization of settlements, but also selected elements and processes which can determine relations between settlements within the system of settlements and their relations towards spatial development.

The importance of each settlement in the network of all settlements is based on its size, functional de- 
Table 4. Indicators used for the categorization of settlements in Slovenia

\begin{tabular}{|l|l|}
\hline Indicator & Source \\
\hline degree of centrality of settlements & Benkovič Krašovec, 2006; Cigale, 2002 \\
\hline number of inhabitants & SORS, 2002 census \\
\hline number of working places & $\begin{array}{l}\text { SORS, } 2002 \text { census (Persons in employment by settlement of } \\
\text { employment) }\end{array}$ \\
\hline $\begin{array}{l}\text { share of working active population not working in the } \\
\text { settlement of residence }\end{array}$ & $\begin{array}{l}\text { SORS, 2002 census (Persons in employment by settlement of } \\
\text { residence) }\end{array}$ \\
\hline
\end{tabular}

termination (degree of centrality or provision of settlements with central activities) and economic significance of the settlement (number of jobs in settlements). Categorization of settlements in Slovenia was therefore determined according to four indicators:

1. number of inhabitants;

2. degree of centrality of settlements;

3. number of working places;

4. share of working active population not working in the settlement of residence.

Categorization of settlements according to abovementioned indicators comprises a selection of 590 central places in Slovenia and 206 settlements which are not central places, but have more than 100 working places. Finally, 796 settlements in Slovenia were included in the categorization ( $13.2 \%$ of all settlements in Slovenia). Other settlements have low economic importance with emphasized dwelling function. Categorized settlements are also population nodes.

Each settlement analysed in the categorization was classified into one of six classes in order to standardize data on the same measurement scale and to follow the logic of distribution of central settlements. The next step of categorization was typification of settlements based on the combination of all four indicators used in the analysis. The final result of the analysis was the categorization of settlements on 6 levels to keep the standardized measurement scale. Those levels were named using the most common terms for determining the system of settlements.

\section{Results and discussion}

Settlements used in the categorization were delineated on 2 macro-regional, 15 regional, 52 sub-regional, 142 local, 299 sub-local and 286 micro-local centres.

Ljubljana and Maribor are macro-regional centres. They are the most important central settlements, nodes of population and economic development. Apart for two macro-regional centres there are also 15 regional centres (Brežice, Celje, Jesenice, Koper, Kranj, Krško, Murska Sobota, Nova Gorica, Novo mesto, Postojna, Ptuj, Ravne na Koroškem, Slovenj Gradec, Trbovlje and Velenje), which are relatively evenly distributed throughout the national territory.
Some of them are spatially close to each other (Ravne na Koroškem-Slovenj Gradec and Krško-Brežice), forming conurbations. Sub-regional centres are mostly sits of ex-municipalities or communes which were in place from socialist times until the reform of local self-governance in 1993. During the old municipal system they got many central functions (schools, health service, administration) and economic activities from secondary and service sectors. Therefore, their role as inter-municipal centres is still evident in the system of settlements in Slovenia. The network of local, sublocal and micro-local centres is denser in the eastern part of Slovenia, where population density is higher. However, the network of all categorized settlements is quite well dispersed. Local centres are often larger settlements with emphasised economic function, but not necessarily having central place functions.

Some of categorized settlements are spatially adjacent. They can be incorporated into agglomerations. Agglomeration is a group of neighbouring categorized settlements that are spatially adjacent with possible functional connections. The importance of agglomeration is determined according to the highest-ranked settlement in the agglomeration. Ljubljana agglomeration of macro-regional importance is the largest agglomeration in Slovenia covering majority of the Ljubljana functional region and stretching along the highway corridors. All regional centres with the exception of Novo mesto have its own agglomeration. Although they are small, agglomerations are formed also on local levels. Results of categorization show that system of settlements in Slovenia follows principals of dispersed decentralization and formation of urban regions which is a recent development pattern of the system of settlements in the developed world (Ravbar, 2004).

On the other hand, categorization of settlements in Slovenia points out, that hierarchy between settlements still exists. But the hierarchy inside the system of settlements is changing, especially on lower levels. For example, when Cigale (2002) compared results of his research on central-place hierarchy with findings of Vrišer from 1987, he pointed out numerous changes in the central-place relationship, especially on the micro-regional level, where due to the growing impor- 


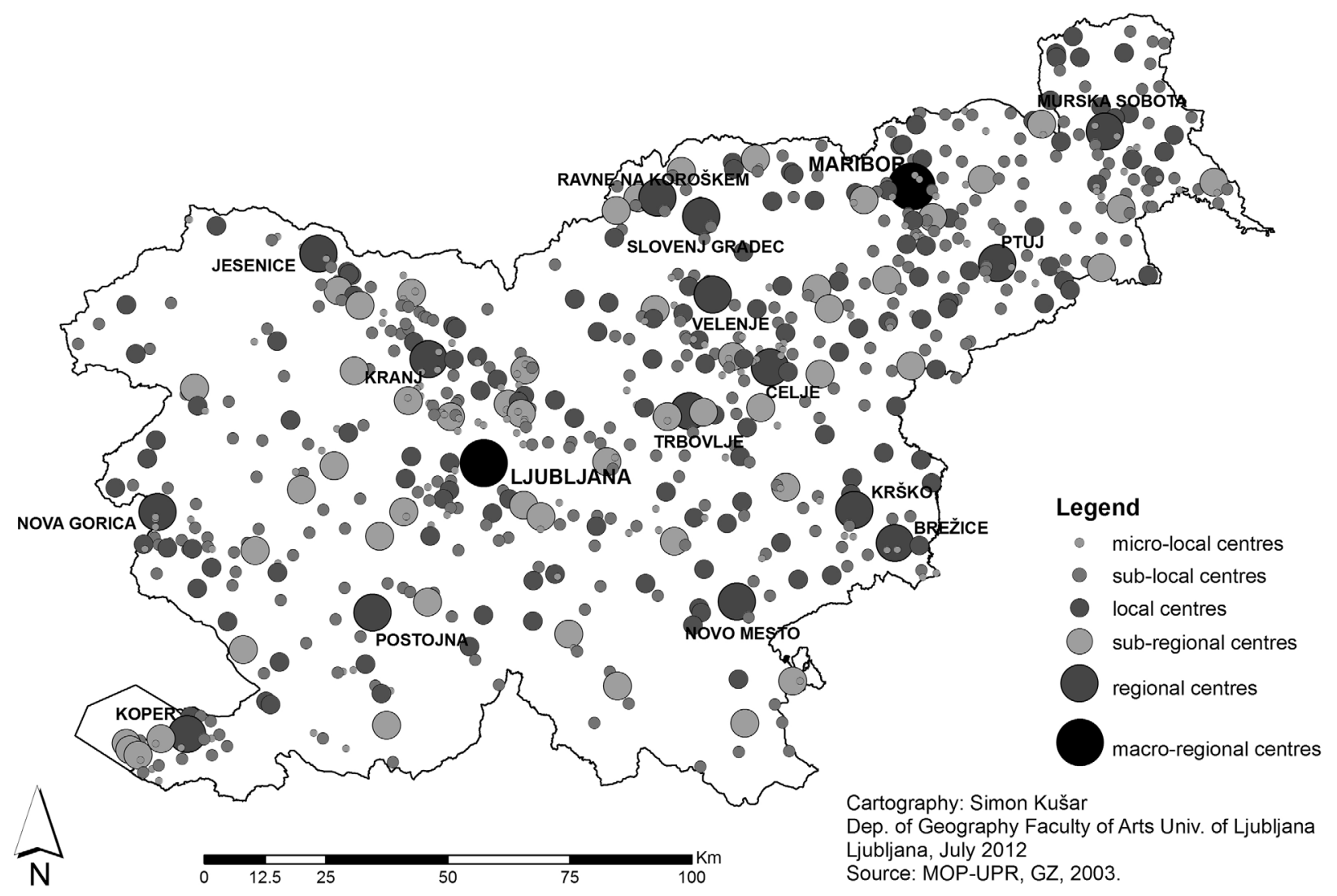

Figure 6. Categorization of settlements in Slovenia

tance of some of smaller centres the network of micro-regional central places has become denser. The importance of small centres, but centres of newly founded municipalities, was estimated to be higher as well (Cigale, 2002; Černe, Kušar, 2012). On the other hand, Ljubljana gained its position as administrative, political, cultural, commercial and educational centre of the Republic of Slovenia, but the categorization of settlements does not present this fact.

It is interesting, that all categorized settlements are not also transport nodes. The transport node is defined as the sum of nodes of all kinds of transport modes intersections and not just one. Only the syner- gy of different transport modes and nodes indicate the degree of connection between transport and the centrality of the settlement. The hierarchy of transport nodes is determined according to the weighted values of hierarchical transportation lines: roads and railways, number of bus lines, airports and ports. Their categorization was prepared using the same methodological approach as in the case of settlement categorization (Černe, Kušar, 2008).

From the spatial distribution of the six-grade hierarchical settlement structure and six-grade hierarchical structure of transport nodes it is evident that only at the highest hierarchical level this structure is iden-

Table 5. Categorization of settlements and transport nodes in Slovenia: comparison of the structure

\begin{tabular}{|l|r|r|r|}
\hline Categories & \multicolumn{1}{|c|}{$\begin{array}{c}\text { Number of } \\
\text { settlements }\end{array}$} & $\begin{array}{c}\text { Number of } \\
\text { transport nodes }\end{array}$ & $\begin{array}{c}\text { Number of evenly categorized } \\
\text { settlements and transport nodes }\end{array}$ \\
\hline Macro-regional & 2 & 4 & 2 \\
\hline Regional & 15 & 12 & 5 \\
\hline Sub-regional & 52 & 26 & 11 \\
\hline Local & 142 & 54 & 21 \\
\hline Sub-local & 299 & 87 & 15 \\
\hline Micro-local & 286 & 28 & 0 \\
\hline Total & 796 & 211 & 54 \\
\hline
\end{tabular}

Source: adapted from Černe, Kušar, 2008 
tical. At regional level, regional centres are often not also the location of regional transport nodes. Just 5 regional centres among 15 coincide with regional transport nodes. In the case of sub-regional centres and sub-regional transport nodes the ratio is even lower: the spatial distribution of 52 centres and 26 transport nodes is identical just in eleven cases. Therefore, we can conclude that spatial structure of the urban system and transport infrastructure, as far as the spatial distribution of its hierarchical elements is concerned, is relatively weak, mostly at lower levels. That means that categorized settlements in Slovenia don't have necessarily also the same position from the transportation point of view.

\section{Conclusions}

The system of settlements in Slovenia is characterized by a large number of settlements, their dispersion and low level of urbanization. There are only two larger towns, of which Ljubljana is much larger than Maribor, and many small towns (141 or $2.3 \%$ ). But a large share $(48.7 \%)$ of population resides in settlements with less than 1,500 inhabitants. Urban system of Slovenia is relatively weak from the European point of view. Only Ljubljana urban region exceeds half a million inhabitants. However, the system of the most important settlements in Slovenia is included on maps showing territorial potentials in the enlarged European Union.

Comparison of three approaches used to analyse the system of settlements in Slovenia (central settlements, planned polycentric urban system and categorization of settlements) indicates similar results. According to central settlements analysis and categorization of settlements there are 2 most important settlements (macro-regional centres) in Slovenia: Ljubljana and Maribor. Planned polycentric urban system adds to macro-regional centres also coastal conurbation Koper-Izola-Piran. On the second highest level (regional centres) same settlements are placed in all three cases except for Koper that is placed in the group of national urban centres of international significance in the case of the planned urban system as proposed by Spatial Development Strategy of Slovenia (2004). First differences between all three approaches appear on the sub-regional level, where categorization of settlements has 52 settlements, central settlements system 79 (but it includes 2 macro-regional and 15 regional centres, which follows the theory that all settlements of the higher level automatically reflect functions of central settlements of lower levels) and planned system of settlements 15 urban centres of regional significance and 20 urban centres of inter-municipal significance.
The system of settlements in Slovenia is, independently on the used categorization, governed by less than 70 settlements in which main economic functions and majority of population are situated. On the other hand, the vast majority of settlements in Slovenia is despite the polycentric spatial development paradigm form 196os on and decentralized, even dispersed development of small economic activities before and after the independence in 1991 mainly without any significant economic functions that would be important for their development or development of other settlements. They are either small rural villages or larger settlements located mostly in suburban areas with emphasized dwelling function. Rural settlements are of vital importance in Slovenia since their number and number of population settling in them remains high. As important part of rural population commutes daily in economic centres to work it is expected, that pressures on building new houses in rural areas will continue. Although this might cause additional environmental pressures due to pollution of air, consumption of nonrenewable resources, building on agricultural land and further dispersion of settling the process will be important from the point of the national regional policy goals that emphasize polycentric development and prevention from depopulation. However, rural settlements around important economic nodes are in a better position, but on the other hand it is expected that the most peripheral settlements will be confronted with further depopulation.

The system of settlements in Slovenia is changing. It is witnessing partial disintegration of hierarchical levels on lower levels and the growth of importance in the highest levels, especially of Ljubljana. Surprisingly, the traditional and alternative approaches used to analyse the system of settlements in Slovenia are not reflecting these changes. Even the alternative approach that used more than one indicator to analyse the system of settlements is not bringing much value added to knowledge about the system of settlements in Slovenia. Therefore, future research on the system of settlements in Slovenia should be directed toward integrating traditional indicators and indicators presenting development dynamics together with European dimension of individual settlements.

\section{References}

2002 Census. Statistical Office of the Republic of Slovenia (SORS).

Benkovič Krašovec, M. 2006. The role of central settlements of first and second level in developing Slovenian rural areas: $\mathrm{PhD}$ thesis. Department of Geography Faculty of Arts University of Ljubljana, Ljubljana, 215 pp. (in Slovenian) 
Bole, D. 2008. Economic transformation of Slovenian cities. ZRC Publishing, Ljubljana, 232 pp. (in Slovenian with English summary)

Cigale, D. 2002. Central places in Slovenia and their spheres of influence in 1999. Geographical Bulletin 74-1, 43-56. Internet: http://zgds.zrc-sazu.si/gv741-cigale.pdf (24. 7. 2012). (in Slovenian with English summary)

Černe, A., Pelc, S. 1992. Urban system and traffic system in Slovenia. Geographica Slovenica, 125-137 (in Slovenian with English summary)

Černe, A., Kušar, S. 2008. The urban system and transportation infrastructure in Slovenia. Uticaj prometa na regionalni razvoj. Zbornik radova. Tuzla, 17.-18.9.2007. Univerzitet u Tuzli, Prirodno matematički fakultet, Tuzla, 31-42.

Černe, A., Kušar, S. 2012. Haloze: less developed area. Geographic Horizon 1-2, 36-43. (in Slovenian)

Černe, A., Kušar, S., Guzelj, T., Kokole, V., Lenarčič, L. 2007. Categorization of the settlement and traffic networks of the Republic of Slovenia for the preparation of the national strategic spatial plan. Department of geography, Faculty of Arts, University in Ljubljana, Ljubljana, 201 pp. (in Slovenian)

Drozg, V. 2002. Preserving regional diversity of residential buildings in Slovenia. Dela 18, 449-461. Internet: http://www.ff.uni-lj.si/oddelki/geo/publikacije/dela/files/Dela_18/33\%2odrozg.pdf (25. 7. 2012) (in Slovenian with English summary)

Hammond, R., McCullagh, P. 1974. Quantitative techniques in geography: an introduction. Clarendon press, Oxford, $318 \mathrm{pp}$.

Kladnik, D. 2004. Settling and settlements. Slovenia: a Geographical Overview. Association of Geographical Societies in Slovenia, ZRC Publishing, Ljubljana, 93-10o. Internet: http://zgs.zrc-sazu.si/Portals/8/ Slo_Geo_Over/17.pdf (23. 7. 2012).

Kokole, V. 1975. Basis of polycentric urban system in SR Slovenia. Zavod SRS za regionalno prostorsko planiranje, Ljubljana, 66 pp. (in Slovenian)

Kušar, S., Pichler-Milanović, N. 2010. Ljubljana in the system of settlements and centres. GeograFF 8, 55-69.

Melik, A. 1935. Slovenia: geographical description. Slovenska matica, Ljubljana, 700 pp. (in Slovenian)

Orožen Adamič, M. 2004. Slovenia: a geographical overview. Slovenia: a Geographical Overview. Association of Geographical Societies in Slovenia,
ZRC Publishing, Ljubljana, 5-6. Internet: http:// zgs.zrc-sazu.si/Portals/8/Slo_Geo_Over/1.pdf (25. 7 . 2012).

Ravbar, M. 2004. The network of settlements and the development of urbanization in Slovenia at the start of the 21st Century. Slovenia: a Geographical Overview. Association of Geographical Societies in Slovenia, ZRC Publishing, Ljubljana, 101-104. Internet: http://zgs.zrc-sazu.si/Portals/8/Slo_Geo_ Over/18.pdf (23. 7. 2012).

Rebernik, D. 2004. Recent development of Slovene towns - social structure and transformation. Dela 21, 139-144. Internet: http://www.ff.uni-lj.si/oddelki/ geo/publikacije/dela/files/Dela_21/015\%2orebernik. pdf (25. 7. 2012)

Register-based Census, 2011. Statistical Office of the Republic of Slovenia (SORS).

SI-Stat Data Portal. Statistical Office of the Republic of Slovenia (SORS). Internet: http://pxweb.stat.si/ pxweb/Dialog/statfile1.asp (24. 7. 2012).

Spatial Development Strategy of Slovenia. 2004. Ministry of the Environment, Spatial Planning and Energy, Ljubljana, 79 pp. Internet: http://www.arhiv. mop.gov.si/fileadmin/mop.gov.si/pageuploads/ publikacije/drugo/en/sprs_eng.pdf (23. 7. 2012).

Regulations of the local self-governance. 1999. Uradni list Republike Slovenije, Ljubljana, 152 pp. (in Slovenian)

Territorial units and house numbers, Slovenia, 1 April 2012 - final data. Internet: http://www.stat.si/eng/ novica_prikazi.aspx?id=4648 (24. 7. 2012).

Tosić, B. 2009. System of centres, the city of Belgrade and territorial organization of Serbia. Dela, 31, 55-78. Internet: http://www.ff.uni-lj.si/oddelki/geo/publikacije/dela/files/dela_31/o4_tosic.pdf (23. 7. 2012).

Urban settlements in the Republic of Slovenia, 2003. 2004. Special publications, 3. Statistical Office of the Republic of Slovenia, Ljubljana, 140 pp. Internet: http://www.stat.si/doc/pub/mestna_naselja_ slo_03.pdf (28.1.2009).

Vrišer, I. 1980. Settlement system in Yugoslavia. Geographical Bulletin 52, 93-105. (in Slovenian)

Zupančič, J. 2007. Roma settlements as a specific part of settlement system in Slovenia. Dela, 27, 215-246. Internet: http://www.ff.uni-lj.si/oddelki/geo/Publikacije/Dela/files/Dela_27/12_zupancic.pdf (25. 7 . 2012) (in Slovenian with English summary) 